\title{
Sie sind eingeladen!
}

Ihre Treue ist uns was wert: Wir laden Sie, liebe Abonnentinnen und Abonnenten von ergopraxis, zu unserer Abendveranstaltung „ergopraxis after work“ zum Thema „Autismus“ ein.

Als Referentin für den Abend konnten wir Christine Preißmann, Ärztin und Autistin, gewinnen. Sie wird darüber sprechen, wie es sich mit der Diagnose „Asperger“ lebt, welche Unterstützung betroffene Kinder, Jugendliche und Erwachsene benötigen und welche Perspektiven sie haben. Dazu gewährt Christine Preißmann Einblicke in ihr eigenes Erleben mit Asperger. Sie dürfen gespannt sein auf eine facettenreiche Welt, in der es manchmal einsam, aber oft auch überraschend bunt und unkonventionell zugeht.

Kommen Sie am 22. September 2015 zu uns in den Georg Thieme Verlag nach Stuttgart. Der Eintritt ist für Sie als Abonnenten frei. Falls Sie Kollegen oder Klienten mitbringen möchten sehr gerne. Für sie kostet der Eintritt 19 Euro.

Damit wir besser planen können, bitte ich Sie, sich bis zum 1. September 2015 unter www.thieme.de/ergopraxis-after-work anzumelden.

Herzliche Grüße und vielleicht bis im September in Stuttgart Ihre
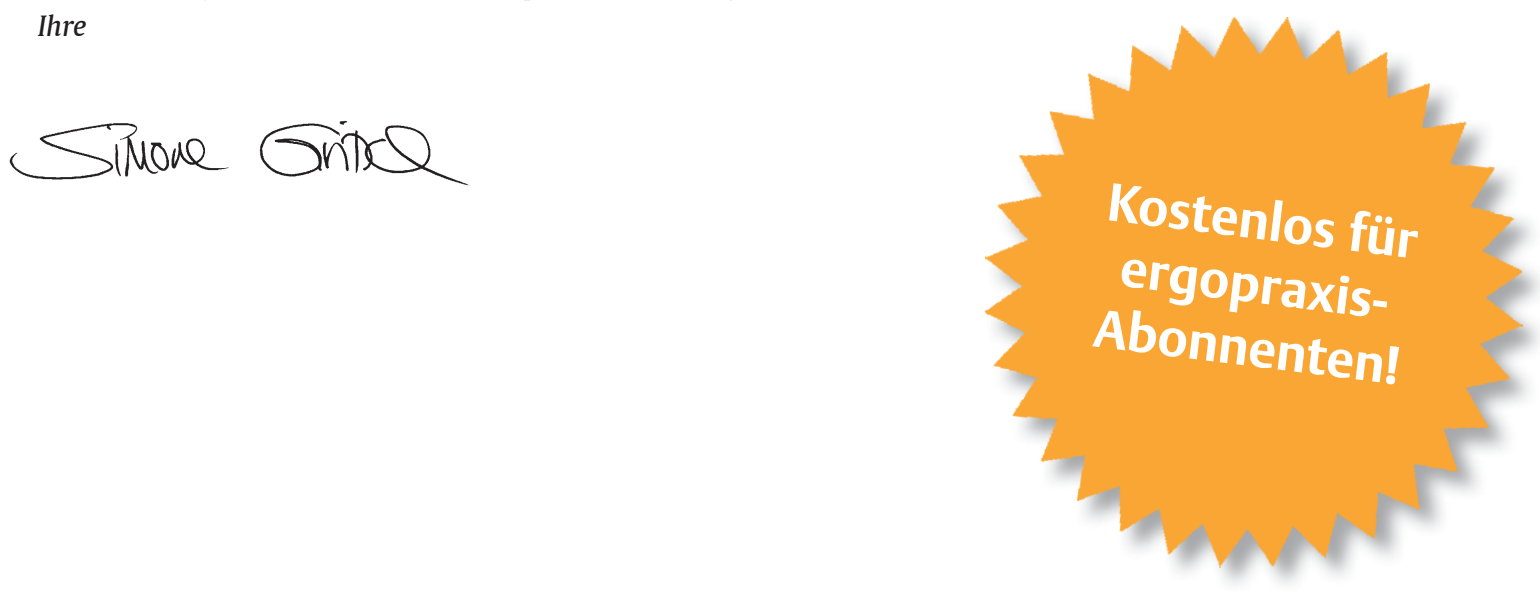